\title{
PENGGUNAAN PERMAINAN PUZZLE CARAKAN DALAM PEMBELAJARAN MENULIS AKSARA JAWA DI SEKOLAH DASAR
}

\author{
Windri Maryana ${ }^{1}$, Laili Rahmawati ${ }^{2}$, Krisma Anugra Malaya ${ }^{3}$ \\ windrimaryana98@gmail.com¹ , lailyrahmawati36@gmail.com², \\ krismaanugra1810@gmail.com ${ }^{3}$ \\ PGSD, FKIP, Universitas Muhammadiyah Surakarta ${ }^{1}$
}

\begin{abstract}
Abstrak: Aksara Jawa merupakan salah satu pelajaran yang dirasa cukup sulit untuk siswa Sekolah Dasar. Cara mengajar guru yang masih konvensional menjadi salah satu faktor penyebabnya. Penggunaan media pembelajaran dengan menggunakan permainan edukasi merupakan salah satu solusi untuk guru dalam mengajar. Puzzle carakan merupakan salah satu bentuk inovasi yang dapat digunakan untuk merangsang otak anak. Bermain sambil belajar akan membuat anak lebih tertarik sehingga anak tidak akan merasa cepat bosan.Tujuan daripenelitian ini adalah: (a) Untuk mengetahui mekanisme penggunaan media Puzzle Carakan dalam pembelajaran menulis aksara Jawa.(b) Untuk mengetahui bagaimana pengaruh penggunaan media Puzzle Carakan dalam pembelajaran menulis aksara Jawa. Jenis penelitian ini menggunakan pendekatan Deskriptif Kualitatif. Teknik analisis data yang digunakan yaitu dengan cara menganalisis jawaban siswa, serta perbandingan hasil belajar siswa sebelum belajar menggunakan Puzzle Carakan dan sesudah menggunakan Puzzle Carakan.
\end{abstract}

Kata kunci: puzzle, carakan, aksara jawa, sekolah.

\section{USE OF PUZZLE GAME WAY IN LEARNING TO WRITE JAVA SCRATCHES IN ELEMENTARY SCHOOL}

\begin{abstract}
Javanese script is one of the subjects that is considered quite difficult for elementary school students. The conventional way of teaching teachers is one of the contributing factors. The use of learning media using educational games is one solution for teachers in teaching. Puzzles are a form of innovation that can be used to stimulate children's brains. Playing while learning will make children more interested so that children will not feel bored quickly. The aims of this study are: (a) To find out the
\end{abstract}


Windri, Laili, Krisma. PenggunaanPermainan Puzzle Carakan... mechanism of using Puzzle Carakan media in learning to write Javanese script. (b) To find out how the effect of using Puzzle Carakan media in learning write Javanese characters. This type of research uses a qualitative descriptive approach. The data analysis technique used is by analyzing student answers, as well as comparing student learning outcomes before learning to use Puzzle Carakan and after using Puzzle Carakan.

Keywords: puzzle, method, Javanese script, school.

\section{PENDAHULUAN}

Indonesia adalah negara maritim yang memiliki banyak pulau. Kondisi ini sangat berpengaruh terhadap kebudayaan di Indonesia sehingga mengakibatkan keberagaman agama, suku, adat, dan bahasa dalam tiap-tiap daerah. Ada sekitar 741 bahasa daerah (bahasa ibu) yang tersebar di Indonesia dari Sabang sampai Merauke. Dalam setiap bahasa daerah tersebut pastinya memiliki keunikan dan sendiri yang mencermintan identitas darimasing-masing daerah.

Saat ini perkembangan bahasa daerah terutama bahasa jawa selalu dijadikan sebagai muatan lokal dalam sekolah formal di Jawa Tengah mulai dari jenjang SD (Sekolah Dasar), SMP (Sekolah Menengah Pertama) dan SMA (Sekolah Menengah Atas). Dalam pelajaran bahasa jawa tidak hanya akan dikenalkan dengan kosa kata tetapi juga dikenalkan dengan huruf-huruf jawa yang biasa disebut dengan nama aksara carakan (akasara jawa). Aksara jawa sendiri memiliki bermacam bentuk yaitu aksara carakan, sandhangan, aksara pasangan, aksara rekan, aksara murda, aksara swara (Lestari, 2009). Aksara jawa yang digunakan terdiri dari dua puluh aksara pokok yang memiliki sifat silabik (Yayasan Pustaka Nusantara, 2002)

Berdasarkan penelitian yang dilakukan oleh (BAPPEDA (Badan Perencanaan dan Pembangunan daerah) DIY, 2004) mengenai pembelajaran bahasa Jawa di lapangan, diperoleh hasil bahwa 93\% guru di SD dan SMP hanya menggunakan metode ceramah dalam setiap penyampaian materi pembelajaran. Selain itu media pembelajaran terbatas pada media tradisional seperti gambar dinding dan kaset tembang (Ekowati dalam Mulyana, 2008: 243).

Dalam pembejaran di SD metode pengajaran yang sering guru digunakan masih konvensional. Seperti yang telah diketahui dalam pembelajaran bahasa jawa yang didalamnya mencakup aksara jawa saat ini biasanya guru akan lebih cenderung 
Windri, Laili, Krisma. PenggunaanPermainan Puzzle Carakan... menjelaskan dengan metode ceramah sehingga siswa pun kurang tertarik dan mengalami kesulitan. Terlebih lagi dalam penulisan ada beberapa aturan dan juga bentuknya pun beragam bahkan ada beberapa bentuk huruf yang hampir sama. Selain itu,jumlah semua hurufnya pun cukup banyak. Kegiatan pembelajaran yang dilaksanakan oleh guru masih menggunakan metode yang konvensional yang menjadikan pembelajaran bahasa jawa di kelas kurang menarik dan interaktif (Yovita, 2018).

Kondisi pembelajaran yang menyenangkan dan menantang akan memotivasi siswa untuk menjadi pembelajar sejati. Suatu pembelajaran berlangsung sebagai suatu proses saling mempengaruhi antara guru dan siswa. Pembelajaran dapat dikatakan berhasil dan berkualitas apabila seluruhnya atau setidak-tidaknya sebagian besar peserta didik terlibat secara aktif, baik fisik, mental, maupun sosial dalam proses pembelajaran, di samping menunjukkan kegairahan belajar yang tinggi, semangat belajar yang besar, rasa percaya diri, serta berdasarkan dari sikap dan nilai positif yang ditunjukkan terhadap suatu objek atau materi pembelajaran. (Mulyasa dalam Diah Mariana;2014, Stevens; 1995)

Pengunaan media sebagai sarana pembelajaran akan membuat peserta didik untuk lebih aktif dalam proses pembelajaran. Media yang menarik akan mampu menarik minat peserta didik sehingga proses pembelajaran tidak terasa membosankan. Media dapat menggunakan alat maupun media permainan. Media permainan tentunya adalah permainan yang edukatif atau mendidik, bukan hanya sekedar permainan yang dapat membuat anak merasa kelelahan sehingga menjadi malas belajar. Dengan menggunakan sebuah permainan kegiatan belajar akan lebih menyenangkan bagi siswa. alat bermain merupakan termasuk kedalam media pembelajaran, hal tersebut karena didalamnya mengandung pesan yang akan diterima oleh siswa saat bermain (Nurmalita, 2012).

Alat permainan edukatif yang dapat meningkatkan motivasi belajar dan intelegensi atau kecerdasan anak salah satunya yaitu permainan puzzle. Media permainan puzzle dapat meningkatkan konsentrasi siswa, meningkatkan hasil belajar, meningkatkan minat dan kecerdasan siswa (Park dan Park dalam Nuruah; 2013, Widya; 2017, Wayan; 2019, Elan; 2017). Salah satu media puzzle yang dapat digunakan yaitu media puzzle gambar berupa potongan-potongan yang dapat disatukan menjadi utuh, puzzle ini merupakan salah satu permainan edukatif yang dapat meningkatkan dan 
Windri, Laili, Krisma. PenggunaanPermainan Puzzle Carakan... mengembangkan kreatifitas siswa (Wahyuni dalam Nuriah; 2013, Rokhmat dalam Srianis; 2014, Anirisa; 2017, Rista; 2020).

Media puzzle yang dimodifikasi sehingga memuat pembelajaran aksara Jawa membuat siswa lebih mudah untuk mengingat karena pembelajaran dilakukan dengan media permainan. Sehingga, akan membantu untuk merangsang daya ingat siswa dalam mengingat pelajaran yang dirasa sulit. Media puzzle ini nantinya akan digunakan untuk mengukur kemampuankognitif anak sebelum menggunakan media puzzle dan sesudah menggunakan media puzzle dalam pembelajaran akasara Jawa.

Tujuan penelitian ini adalah untuk mengetahui pengaruhpenggunaan media pembelajaran berupa permainan puzzle carakan terhadap kemampuan siswa dalam menulis aksara jawa dalam upaya peningkatkan intelegensi siswa dalam aksara carakan.

\section{METODE}

Jenis penelitian ini menggunakan pendekatan Deskriptif Kualitatif. Lofland \& Lofland (dalam Moleong, 2010: 157) mengatakan bahwa sumber data utama dalam penelitian kualitatif adalah kata-kata dan tindakan, selebihnya adalah data tambahan seperti dokumen dan lain-lainnya. Dokumen yang digunakan yaitu berupa data dari guru pengajar yang telah menggunakan media pembelajaran PUZZLE ini. Penelitian ini dilakukan dengan cara menganalisis jawaban siswa atau peserta didik dan guru, selain itu juga adanya perbandingan siswa sebelum belajar menggunakan puzzle dan sesudah menggunakan puzzle.

Waktu, tempat, dan jenis kegiatan penelitian di SD NegeriPajang 1 No. 93 Surakarta, merupakansalahsatu SD Negeri di Surakarta. Sedangkan waktu pelaksanaannya dilaksanakan selama 3 bulan.Subjek dalam penelitian ini adalah media pembelajaran Puzzle untuk pembelajaran aksara Jawa. Objek Penelitian ini adalah pemahaman anak terhadap aksara Jawa setelah belajar menggunakan Puzzle.Dalam penelitian ini, penulis fokuskan kepada anak-anak kelas IV SD N Pajang 1 No. 93 Surakarta dengan menggunakan 2 metode pembelajaran. Metode pertama yaitu pembelajaran dengan cara konvensional yaitu metode ceramah dan yang kedua dengan menggunakan media puzzle sebagai alat pembelajaran.Kegiatan analisis jawaban siswa sebelum dan sesudah menggunakan media pembelajaran puzzle, sehingga dapat 
Windri, Laili, Krisma. PenggunaanPermainan Puzzle Carakan...

diketahui siswa lebih mudah belajar bahasa Jawa menggunakan puzzle atau tidak menggunakan puzzle.

Instrumen evaluasi yang digunakan dalam penelitian ini antara lain: (a) Daftar Nama Siswa. (b) Soal aksara Jawa. (c) Lembar jawaban siswa sebelum menggunakan media pembelajaran puzzle dan sesudah. Teknik validasi data dilakukan dengan menggunakan teknik trianggulasi sumber data. Trianggulasi adalah teknik pemeriksaan keabsahan data yang memanfaatkan sesuatu yang lain diluar data itu untuk keperluan pengecekan atau sebagai pembanding terhadap data itu (Moleong, 2010: 330). Patton (dalam Moleong, 2010: 330, Denzin; 2009) mengatakan bahwa teknik trianggulasi sumber data berarti membandingan dan mengecek balik derajat kepercayaan suatu informasi yang diperoleh melalui waktu dan alat yang berbeda dalam penelitian kualitatif. Teknik analisis data yang digunakanyaitu media pembelajaran Puzzle dalam mata pelajaran bahasa jawa, dimana aksara jawa menjadi focus dalam analisis penelitian ini. Adanya data dari guru pengajar yang dapat dijadikan sebagai perbandingan.

\section{HASIL}

\section{Metode Ceramah}

Metode Ceramah adalah metode pembelajaran yang penyampaian informasinya dilakukan secara lisan oleh guru atau pengajar. Dalam metode ini guru dituntut untuk benar-benar memahami materi. Dalam penelitian ini, variasi metode ceramah yang digunakan adalah tanya jawab, ceramah dan tugas. Jika biasanya guru menyampaikan informasi di depan kelas, kemudian siswa diberikan kesempatan untuk melakukan tanya jawab dan setelah itu guru memberikan tugas atau memberikan soal kepada siswa, Maka penelitian penulis ini dimulai dari penulis memberikan pertanyaan kepada siswa, kemudian penulis menjelaskan materi, setelah itu baru memberikan tugas untuk mengerjakan soal-soal.

Ketika penulis pertama masuk ke dalam kelas, para siswa terlihat sangat gaduh karena banyak siswa yang meneteskam air matakarenaperpisahan dengan teman sekelas mereka yang akan pindah. Setelah pengkondisian kelas, penulis mencoba bertanya kepada para siswa terkait aksara jawa (carakan) yang pernah diberikan oleh guru mereka sebelumnya. Tujuan penulis melakukan tanya jawab adalah untuk mengetahui sudah sejauh mana mereka memahami aksara jawa (carakan) yang telah mereka 
Windri, Laili, Krisma. PenggunaanPermainan Puzzle Carakan...

dapatkan. Kemudian penulis meminta siswa untuk menuliskan aksara jawa (carakan) secara bergantian di depan kelas. Saat sesi ini berlangsung, para siswa sangat antusias untuk menjawab, hingga kelas menjadi ricuh dan gaduh. Mereka berlomba-lomba untuk mengangkat tangan dan berteriak-teriak untuk menuliskan aksara jawa yang mereka ketehui. Ketika ada dari mereka yang tidak penulis tunjuk, mereka akan memperlihatkan ekspresi kecewa yang sangat kentara. Namun saat penulis sudah menunjuk siswa untuk ke depan, tidak semua siswa mampu menuliskan dengan benar. Ada beberapa siswa yang masih bingung membedakan antara huruf yang satu dengan yang lainnya.

Setelah mengulas sedikit pengetahuan mereka melalui tanya jawab, kemudian penulis menjelaskan materi tentang aksara jawa (carakan). Saat pembelajaran berlangsung siswa kebanyakan bersikap pasif tetapi juga sangat ricuh dan sulit diatur. Mereka cenderung diam dan tidak terlalu banyak bertanya. Tetapi tidak semua siswa memiliki karakter yang demikian, ada beberapa siswa yang bahkan selalu bertanya pada hal-hal yang menurut mereka baru dan berusaha untuk mencari tahu. Tetapi selama proses pembelajaran siswa yang aktif kebanyakan selalu ribut sendiri, seperti mengobrol dengan teman yang lain, jahil dan menggerak-gerakkan tubuhsehingga agaksulit untuk diatur. Kebanyakan yang sangat antusias adalah siswa laki-laki. Sedangkan siswa yang perempuan cenderung mengikuti intruksi dengan benar.

Dalam kelas yang berjumlah 36 siswa, terdapat beberapa siswa yang tidak mendengarkan materi yang disampaikan dengan benar. Mereka kebanyakan adalah siswa perempuan yang duduk dibelakang. Mereka malah asyik bercerita sendiri dan terlihat seperti menyepelekan. Selain itu ada juga siswa memang tidak suka dengan materi yang sedang diajarkan yaitu aksara jawa (carakan). Saat dijelaskan mereka akan memperhatikan dengan ogah-ogahan, izin ke kamar mandi lama sekali sehingga apa yang disampaikan oleh guru tidak mampu mereka pahami dengan baik. Meskipun begitu ada juga siswa yang mendengarkan materi dengan tenang. Mereka terlihat menyimak dengan seksama, bahkan ada beberapa siswa yang mencatat materi yang disampaikan.

Setelah penyampaian materi, penulis memberikan tugas kepada siswa berupa soal-soal yang harus mereka kerjakan. Saat penulis memberi tahu bahwa mereka akan diberi soal, mereka ribut-ribut sendiri danmenolak jika disuruh untuk mengerjakan soal, 
Windri, Laili, Krisma. PenggunaanPermainan Puzzle Carakan...

bahkan kelas kembali ricuh dan gaduh. Banyak siswa yang protes bahkan hingga maju kedepan. Perlu waktu untuk bisa menenangkan mereka. Hingga akhirnya penulis membagikan soal dan memberikan waktu 10 menit untuk soal. Jumlah soal yang penulis berikan adalah 5 soal. Saat mengerjakan soal, mereka kembali gaduh karena merasa kesulitan dengan soal-soal yang diberikan. Mereka berteriak-teriak memanggil penulis untuk bertanya apakah jawaban yang mereka kerjakan sudah tepat atau belum. Ada juga yang bertanya terkait soalnya. Sedangkan siswa yang mendengarkan penjelasan materi dengan tidak fokus, mereka protes dan berkata jika tidak bisa mengerjakan. Mereka beralasan jika mereka tidak suka pelajaran aksara jawa(carakan) bahkan mereka meminta untuk soalnya lebih baik matematika saja. Selama sesi mengerjakan soal ini, penulis benar-benar harus ekstra menjaga siswa-siswa untuk tidak mencontek dan berteriak-teriak agar kelas tidak gaduh.

Ketika waktu yang penulis tentukan hampir habis, kelas kembali ricuh dan gaduh. Mereka berteriak-teriak dan mengeluhkan waktunya sangat cepat. Saat penulis meminta siswa untuk mengumpulkan jawaban di depan kelas, awalnya yang mengumpulkan hanya sedikit. Tetapi setelah penulis hitung mundur akhirnya mau tidak mau mereka harus mengumpulkan jawaban kedepan meskipun dengan jawaban asalasalan karena tergesa-gesa.

\section{Media Puzzle Carakan}

Setiap anak memiliki cara belajar yang berbeda-beda antara anak satu dengan anak yang lainnya, begitu pula dalam kegiatan pembelajaran didalam kelas. Antusias anak dalam belajar dikelas pun berbeda-beda, anak akan merasa bosan dengan model pembelajaran yang sama setiap harinya seperti metode ceramah. Dengan menggunakan hal baru dikelas dalam belajar anak akan merasa tertarik dan penasaran, hal baru tersebut seperti pembelajaran yang menggunakan media pembelajaran dalam belajar. Media pembelajaran yaitu alat bantu dalam proses belajar mengajar, atau segala sesuatu yang dapat dipergunakan untuk merangsang pikiran, perasaan, perhatian dan kemampuan atau ketrampilan belajar sehingga dapat mendorong terjadinya proses belajar pada peserta didik. Misalnya penggunaan media pembelajaran puzzle carakan, media pembelajaran ini diharapkan mampu membantu siswa dalam belajar aksara jawa dan sandhangannya. penulis memilih salah satu sd di daerah Surakarta untuk 
Windri, Laili, Krisma. PenggunaanPermainan Puzzle Carakan... menerapkan media pembelajaran puzzle carakan ini, dan sekolah tersebut sebelumnya belum pernah menggunakannya.

Saat penulis memberikan penjelasan bahwa nanti akan ada kegiatan bermain dan belajar menggunakan puzzle carakan mereka sangat antusias dan semangat karenamereka sebelumnya belum pernah melakukannya. Ada beberapa siswa laki-laki yang meremehkan permainan tersebut karena dianggap sudah biasa dan gampang untuk dilakukan, ada pula siswa yang asyik sendiri mengganggu temannya sehingga kondisi kelas yang tidak kondusif. Sebelum permainan dimulai penulis membagi mereka menjadi dua kelompok yaitu kelompok siswa laki-laki dan perempuan, saat pembagian kelompok siswa laki-laki lebih sulit diatur karena sibuk bermain sendiri dan tidak mendengarkan instruksi yang telah penulis berikan, berbeda dengan siswa perempuan yang lebih penurut. Setelah kelompok selesai dibentuk setiap kelompok diberikan sebuah media pembelajaran yang berbentuk puzzle carakan, setiap kelompok diberi waktu sepuluh menit untuk menyusun puzzle carakan tersebut.

Saat setiap kelompok menyusun puzzle carakan tersebut ada beberapa hal yang terjadi seperti di kelompok siswa laki-laki tidak semua siswa ikut menyusun karena ada anak yang ingin berkuasa dan menyusunnya sendiri tanpa memperdulikan temannya yang lain dank arena kondisi tempat yang kurang luas sehingga siswa dalam menyusun kurang leluasa sehingga ada beberapa sisiwa yang memilih tidak ikut menyusun dan bermain hal lain sendiri. Sedangkan pada siswi perempuan mereka sangat semangat dan antusias dalam menyususn, namun ada pula siswi perempuan yang enggan ikut menyusun karena tidak tertarik dengan aksara jawa sehingga memilih untuk diam saja dan hanya melihat temannya yang sedang menyusun, ada pula siswi yang menyepelekan dan suka membantah saat diberi tau untuk ikut berpartisipasi dalam permainan puzzle tersebut.

Tidak terasa waktu yang diberikan telah habis dalam penyususnan puzzle, perwakilan dari setiap kelompok laki-laki dan perempuan mengumpulkan hasil penyusunan media pembelajaran puzzle tersebut. Saat kedua kelompok sudah mengumpulkan penulis pun secara bersama-sama dengan mereka mengoreksi hasil penyusunannya, dan hasil yang diperoleh yaitu kelompok laki-laki lebih dulu selesai tetapi ada beberapa puzzle yang tertukar letaknya sedangkan untuk kelompok perempuan selesainya lebih lama tetapi penyusunan puzzelnya tepat dan tidak ada yang 
Windri, Laili, Krisma. PenggunaanPermainan Puzzle Carakan...

tetukar. Jadi dari setiap kelompok terdapat kekurangan dan kelebihan yang berbedabeda yang dapat dijadikan sebagai sebuah pengalaman dan pembelajaran, yaitu dalam melakukan segala sesuatu haruslah teliti dan cekatan dan memperhitungkan penggunaan waktu yang tepat sehingga dapat mendapatkan hasil yang maksimal.

Setelah bermain dan belajar menggunakan puzzle carakan masing-masing siswa diberikan soal sebagai tes pengetahuan setelah belajar sebelumnya, saat mendapatkan soal dan mengerjakansoal dengan tenang dan antusias. Mereka ngengerjakan secara mandiri soal yang diberikan dalam waktu sepuluh menit. Siswa yang telah selesai mengerjakan diperbolehkan mengumpulkan kemeja guru dan kemudian kembali duduk. Dalam hal ini ada beberapa siswa yang memang sejak awal antusias dalam belajar bahasa jawa tetapi ada juga siswa yang asyik sendiri dan tidak mau berpartisipasi dalam penelitian. Ada juga anak yang semangatnya meningkat saat belajar sambil bermain menggunakan puzzle carakan. Setelah semua siswa sudah mengumpulkan jawaban dari soal yang diberikan penulis dapat mengoreksi dan dapat melihat hasilnya sebelum menggunakan model pembelajaran puzzle carakan dan sudah menggunakannya.

\section{PEMBAHASAN}

Dalam bagian ini, akan dibahas mengenai efektivitas dalam pembelajaran aksara jawa(aksara carakan) menggunakan metode ceramah dan menngunakan media pembelajaran puzzle.

Setelah melakukan penelitian dan dianalisis, efektivitas mengajar dengan ceramah untuk kelas IV dalam pembelajaran aksara jawa dirasa masih kurang efektif. Siswa hanya duduk dan terfokus untuk mendengarkan sehingga akan mudah merasa bosan. Tidak ada kesungguhan siswa untuk terlibat di dalam proses belajar, siswa menjadi tidak aktif di kelas, siswa pun tiddak pernah mengemukakan pendapat atau bertanya. Respon siswa selama proses pembelajaran siswa acuh dan tidak memperdulikan pembelajaran. Siswa seperti jenuh selama proses pembelajaran berlangsung. Selain itu metode ceramah juga sering disebut komunikasi satu arah yang cenderung membosankan sehingga materi atau informasi yang disampaikan mudah untuk dilupakan.Tetapi saat awal pembelajaran sebelum penyampaian materi, siswa diberikan beberapa pertanyaan mengenai aksara jawa dan siswa memberikan respon yang positif, mereka saling berebut untuk menjawab soal tersebut. 
Windri, Laili, Krisma. PenggunaanPermainan Puzzle Carakan...

Masa kanak-kanak adalah masa dimana pertumbuhan dan perkembangan kognitif, afektif dan psikomotor pada anak berkembang sangat cepat. Pada masa ini anak mudah sekali dalam menerima hal-hal baru dan memiliki rasa ingin tahu yang tinggi juga kreatifitas yang harus terus diasah. Sebagai seorang guru,hendak nya memberikan wadah untuk anak berkreasi dan senantiasa memotivasi anak untuk terus kreatif. Salah satu wadah yang bisa digunakan yaitu penggunaan permain edukatif seperti puzzle carakan.

Puzzle carakan didesain dengan tujuan untuk membuat siswa lebih aktif dalam proses pembelajaran. Dalam proses pembelajaran menggunakan puzzle ini, siswa terlihat lebih antusian dibandingkan dengan metode ceramah. Komunikasi yang terjadi antara guru dan siswa tidak hanya satu arah, tetapi ada timbal balik darikeduanya. Siswa yang awalnya malas dengan tidak menyimak materi, dan tidak menyukai pembelajaran aksara jawa menjadi lebih antusias dan senang dalam pembelajaran yang dilakukan. Dengan adanya hal tersebut suasana belajar mengajar akan lebih hidup dan berkesan, pembelajaran yang didapatkan oleh siswa akan lebih membekas dan tidak mudah dilupakan oleh siswa karena siswa ikut berperan langsung dalam belajar.

Dalam pembelajaran yang menggunakan puzzle carakan ini, terlihat jelas jika siswa lebih bersemangat dalam mengikuti proses pembelajaran. Para siswa yang sebelumnya saat penjelasan materi oleh guru hanya duduk diam dan mendengarkan, telihat bisa lebih ceria dan mau ikut berperan aktif dalam pembelajaran. Mereka bahkan saling berteriak-teriak dalam menyusun puzzle, merekamerasatertantang dan merasayakindapatmelakukannya. Setelah penyusunanselesaisiswadiberisoal yang bobotnyasamadengansoalsebelumbermain puzzle. Terlihat siswa lebih tenang dalam mengerjakan soal. Tidak seperti saat mengerjakan soal setelah penjelasan materi melaluiceramah, mereka lebih banyak protes, mengeluh dan memintabantuan pada teman yang lain.

Diketahui dalam sebuah penelitian tentang "Efektivitas Media Puzzle Terhadap Kemampuan Menulis Permulaan pada Anak Autistik Kelas I SDLB di SLB N 1 Bantul” oleh Feri (2015), hasil penelitian menunjukkan bahwa kemampuan menulis permulaan mengalami perubahan menjadi lebih baik. Penggunaan media puzzle memiliki pengaruh yang baik terhadap kemampuan menulis permulaan pada anak autistik. Penelitian ini tentu hampir sama dengan penelitian yang penulis lakukan, dimana penggunaan media 
Windri, Laili, Krisma. PenggunaanPermainan Puzzle Carakan... puzzle memiliki perubahan padadayaingat anak tentang aksara jawa. Hanya saja perbedaannya terletak pada metode penelitian yang digunakan dan objek penelitian. Jika penelitian penulis menggunakan metode kualitatif sebagai alat ukur, berbeda dengan penelitian yang dilakukan oleh Feri (2015) yang menggunakan metode kuantitatif. Sedangkan objek yang diamati adalah Sekolah Berkebutuhan Khusus (SLB) Austistik.

Dalam penelitian yang kami lakukan, data yang di peroleh juga dapat diambil dari hasil pembelajaran yang dilakukan. Pada post test pertama dan kedua, rata-rata nilai yang diperoleh dari seluruh siswa mengalami perubahan dan peningkatan. Dari hasil sebelum menggunakan media pembelajarn siswa hanya mampu mengerjakan satu atau dua soal dari 5 soal yang dikerjakan, setelah menggunakan puzzle menjadi lebih dari 2 soal yang mampu dikerjakan. Oleh akmal tentang "Efektivitas Penggunaan Media Puzzle Huruf Hijaiyah dalam Upaya Meningkatkan Pemahaman Siswa Terhadap Materi Baca Tulis Al-Qur'an di SD N Periuk Kots Tangerang" di jelaskan pula bahwa pelaksanaan pembelajaran baca tulis Al-Qur'an kelas III mengalami peningkatan. Hal ini ditunjukkan dengan cepatnya siswa dapat membaca Al-Qur'an pada siklus 2, yakni setelah penggunaan puzzle. Selain itu dari hasil nilai yang diperoleh oleh siswa, rata-rata yang diperoleh adalah diatas KKM.

Disini dapat dilihat bahwasiswa lebih senang dengan metode pembelajaran yang melibatkan dirinya. Tidak melulu guru harus ceramah untuk menjelaskan materi, kalaupun memang harus ceramah, bisa dilakukan dengan ceramah variasi, seperti : ceramah, tanya jawab dan tugas atau ceramah, diskusi, dan tugas. Penggunaan permainan edukasi seperti puzzle carakan ini, selain bisa membuat siswa lebih aktif juga bisa meningkatkan daya ingat dan kreativitas siswa. Karena biasanya anak-anak lebih menyukai hal-hal yang berkaitan dengan permainan atau hal-hal baru yang mampu membuat siswa tertarik.

\section{SIMPULAN}

Aksara jawa merupakan salah satu peninggalan yang masih terus dilestarikan sampai saat ini dengan mengajarkan pada generasi muda. Aksara jawa memiliki makna tersendiri bagi masyarakat jawa. Pengajaran kepada generasi muda diberikan melalui kegiatan pembelajaran di sekolah mulai dari sekolah dasar sampai sekolah menengah atas. Hal tersebut dilakukan untuk mempertahankan eksistensi aksara jawa pada 
Windri, Laili, Krisma. PenggunaanPermainan Puzzle Carakan... generasi penerusnya. Kegiatan pembelajaran aksara jawa disekolah dengan menggunakan media lebih efektif ketimbang hanya dengan ceramah. Dengan mengunakan media siswa akan lebih semangat dan tertarik dalam belajar. Salah satunya menggunakan puzzle carakan, siswa dapat menyusun puzzle dan dapat sambil belajar sehingga siswa akan lebih mudah dalam memahaminya.

\section{UCAPAN TERIMAKASIH}

Penulis mengucapkan banyak terimakasih kepada pihak-pihak yang telah mendukung dan ikut serta dalam penelitian ini. Penulis ucapkan terimakasih kepada kepala sekolah di SD N Pajang 1 No. 93 Surakarta yang telah mengijinkan penulis untuk penelitian disana. Terimakasih kepada guru dan siswa di SD N Pajang 1 No. 93 Surakarta yang telah meluangkan waktunya untuk menjadi bagian penting dalam penelitian ini. Terimakasih kepada Bapak Muhamad Taufik Hidayat dan Alm Ibu Risminawati yang telah memberikan bimbingan serta arahannya. Terimakasih juga kepada UMS sebagai pemberi dana penelitian dan semua pihak yang tidak dapat penulis sebutkan satu persatu.

\section{DAFTAR RUJUKAN}

Febriana Avianto, Yovita. 2018. Pembelajaran Aksara Jawa untuk Siswa Sekolah Dasar dengan Menggunakan Media Board Game. Aksara, 30(1) hlm 135.

Denzin, Norman K. dan Yvonna S. Lincoln (eds.). 2009. Handbook of Qualitative Research. Terj. Dariyatno dkk. Jogjakarta: Pustaka Pelajar.

Dwi Permata, Rista. 2020. Pengaruh Permainan Puzzel Terhadap Kemampuan Pemecahan Masalah Anak Usia 4-5 Tahun. Jurnal PINUS: Jurnal Penelitian Inovasi Pembelajaran, 5(2) hlm 4.

Elan. Dkk. 2017. Penggunaan Media Pazzle untuk Meningkatkan Kemampuan Mengenal Bentuk Geometri. Jurnal PAUD Agapedia, 1(1)

Hastuti, Widya. 2017. Pengaruh Media Puzzle Terhadap Hasil Belajar IPA Konsep Daur Hidup Mahluk Hidup Murid Kelas IV SDN Nomor 25 Panaikang Kecamatan Bisappu Kabupaten Bantaeng. Jurnal PENA: Jurnal Penelitian dan Penalaran, 4(1). 
Windri, Laili, Krisma. PenggunaanPermainan Puzzle Carakan...

Indria Ekowati, Venny. 2008. "Perubahan Sistem Pembelajaran Aksara Jawa". Dalam

Mulyana (Ed). Pembelajaran Bahasa dan Sastra Daerah dalam Kerangka Budaya.Yogyakarta: Tiara Wacana.

Lofland dan Lofland dikutip oleh Dr.Lexy J Moleong. 2010 Metode Penelitian Kualitatif. Remaja Rosdakarya: Bandung

Lestari, E.D. (2009). Kawruh Sapala Basa. Klaten: Intan Pariwara.

Mariana, Diah. 2014. "Puzzle sebagai Media Pembelajaran untuk Meningkatkan Motivasi Belajar Siswa TK Budi Rahayu Yogyakarta”. Skripsi. Yogyakarta: Fakultas Bahasa Dan Seni, Universitas Negeri Yogyakarta.

Nuriah, Alfiatun. 3013. "Efektivitas Kombinasi Pembelajaran Kooperatif Time Token Pictuce Puzzle Pada Materi System Peredaran Darah Di SMP N 2 Gabus Kabupaten Pati”. Skripsi. Semarang: Fakultas Keguruan Dan Ilmu Pendidikan, Universitas Negeri Semarang.

Nurmalita, A., T.T. Hastuti, dan T. Hardiyanti. (2012). "Kartu Remi Jawa (KAREWA): Strategi Efektif Meningkatkan Minat Anak dalam Pembelajaran Aksara Jawa dengan Sistem Queen Card Game”. Jurnal Pelita, 7(1), hlm 39-46.

Anirisa Latut Torikil Maviro. 2017. "Penggunaan Media Puzzle untuk Meningkatkan Hasil Belajar Siswa pada Pembelajaran IPS di Kelas IV MIM Lambaro Aceh Besar”. Skripsi. Banda Aceh: Fakultas Tarbiah dan Keguruan, Universitas Islam Negeri Ar-Raniry.

Moleong, Lexy J. 2010. Metodologi penelitian kualitatif. Remaja Rosdakarya: Bandung Patton yang dikutip oleh Lexy J. Moleong, 2010. Metode Penelitian Kualitatif. Remaja Rosdakarya: Bandung

Stevens, R. J., \& Slavin, R. E. (1995). The cooperative elementary school: Effects on students' achievement, attitudes, and social relations. American Educational Research Journal, 32(2), 321-351.

Srianis, K. 2014. Penerapan Metode Permainan Puzzel Geometri untuk Meningkatkan Perkembangan Kognitif Anak dalam Mengenal Bentuk. E-journal PG-PAUD Universitas Pendidikan Ganesa 2 (1), hlm. 5 
Windri, Laili, Krisma. PenggunaanPermainan Puzzle Carakan...

Tim Jarlit BAPEDA DIY. 2004. Pemberdayaan Bahasa, Sastra, Budaya, dan Aksara Jawa melalui Jalur Formal dan Nonformal dalam Era Multikultur di DIY. Laporan Penelitian. Yogyakarta: BAPEDA Propinsi DIY.

Wahyuningsih, Feri. 2015. "Efektivitas Media Puzzle Terhadap Kemampuan Menulis Permulaan pada Anak Autistik kelas I SLDB di SLB N 1 Bantul”. Skripsi. Yogyakarta: Fakultas Ilmu Pendidikan, Universitas Negeri Yogyakarta

Widiyana, Wayan. Dkk. 2019. Media Pembelajaran Puzzel untuk Meningkatkan Hasil Belajar Siswa Kelas IV pada Kompetensi Pengetahuan IPA.

Yayasan Pustaka Nusantara. (2002). Pedoman Penulisan Aksara Jawa. Yogyakarta: Yayasan Pustaka Nusantara. 